\title{
METHODICAL SPECIFICS OF TEACHING PUPILS THE BASICS OF NANOTECHNOLOGY IN PHYSICS LESSONS IN THE 10TH FORM
}

\author{
МЕТОДИЧНІ ОСОБЛИВОСТІ НАВЧАННЯ УЧНІВ \\ ОСНОВ НАНОТЕХНОЛОГІЙ НА УРОКАХ ФІЗИКИ \\ У 10 КЛАСІ
}

\author{
Yuliia TKACHENKO, \\ Postgraduate Student \\ ЮЛіЯ ТКАЧЕНКО, \\ https://orcid.org/0000-0002-2652-2494 \\ аспірантка \\ julia.tkachenko.0301@gmail.com
Sumy State Pedagogical University Сумський державний педагогічний named after A. Makarenko
$\triangle 87$ Romenska St.,
університет імені А. С. Макаренка
$\triangle$ вул. Роменська, 87 \\ Sumy, Sumy region, 40002 \\ м. Суми, Сумська обл., 40002
}

Original manuscript received: October 06, 2019

Revised manuscript accepted: December 14, 2019

\begin{abstract}
Nowadays quality education for the younger generation is the key to the development of the state. This paper proves that including the separate issues of the basics of nanotechnology in physics lessons will update the content of learning physics and will be the basis for the training of qualified personnel.

The purpose of the article is to reveal the methodological specifics of teaching students the basics of nanotechnology in physics lessons in the $10^{\text {th }}$ form.

The analysis of the textbooks recommended by the Ministry of Education and Science of Ukraine on physics for the 10th forms has been carried out. The article is proposed to include the separate issues of the basics of nanotechnology in the sections "Mechanics» and "Molecular physics and thermodynamics». The methodical recommendations for teaching of the separate issues of the basics of nanotechnology have been developed. The content of the article is a logical continuation of the previously defined methodological specifics of teaching pupils the basics of nanotechnology in the course of physics for the $7^{\text {th }}, 8^{\text {th }}$ and $9^{\text {th }}$ forms, which will contribute to the formation of a comprehensive view of nanotechnology among students and will ensure continuation in studying the basics of nanotechnology. Formation of subject nanotechnological competence has to become a result of learning separate issues of the basics of nanotechnology in physics lessons. The article focuses on the use of non-traditional teaching methods (methods of problem-based learning, interactive methods, project method) when studying relevant issues of nanotechnological topic.

We have drawn a conclusion that the including the separate issues of the basics of nanotechnology in school course of physics will contribute to the formation of high school students' ideas about nanotechnology and will be important step towards the training of specialists capable of developing this new field of science and technology for the economic and technological growth of our country.
\end{abstract}


Key words: nanotechnology education, school course of physics, methodological specifics of teaching pupils the basics of nanotechnology.

Вступ. Наука та технології $€$ рушійною силою розвитку, оскільки технологічні та наукові революції лежать в основі економічного прогресу, вдосконалення систем охорони здоров'я, освіти та інфрраструктури. Держави мають створити відповідні умови для розвитку науки й технологій: забезпечити якісну освіту молоді, підвищення кваліфікації співробітників наукових установ та фахівців відповідних галузей промисловості, матеріально-технічне забезпечення тощо. Одним із ключових факторів якісної освіти покоління, що підростає, $€$ зміст відповідних навчальних дисциплін. Ураховуючи тенденції, що склалися сьогодні в науці, варто приділити увагу формуванню в учнів уявлень про нанонауку й нанотехнології, з якими пов'язують четверту науково-технічну революцію.

Сьогодні, на жаль, зміст навчання фізики в старшій школі не показує в повній мірі рівень розвитку науки й технологій, зокрема й нанотехнологій. Крім того, як показує досвід, більшість учителів не готові включати в уроки питання пов'язані з сучасними досягненнями науки й технологій.

У 2018-2019 н. р. розпочалося вивчення фрізики й астрономії за новими навчальними програмами, рекомендованими Міністерством освіти і науки України наказом № 1539 від 24.11.2017 року. У програмі авторського колективу під керівництвом Локтєва В. М. однією з наскрізних змістових ліній вивчення фрізики $є$ "роль фрізичних знань у житті суспільства, розвитку техніки й технологій, розв'язанні екологічних проблем, нанофізики і нанотехнологій" (Локтєва, 2017), але орієнтовний зміст навчального матеріалу, запропонований авторами, не показує у повній мірі цієї наскрізної змістової лінії. Авторський колектив під керівництвом О.Ляшенка також в одній із наскрізних змістових ліній зазначив нанофізику й нанотехнології. Орієнтовний зміст навчального матеріалу включає тему “Наноматеріали” у 10 класі (Ляшенко, 2017).

Аналіз підручників для 10 класів, рекомендованих Міністерством освіти і науки України, показав, що більшість містить окремі загальні відомості про нанотехнології.

Деякі напрацювання щодо модернізації змісту, методів, форм і засобів навчання фрізики з урахуванням необхідності формування в учнів уявлень про нанонауку і нанотехнології висвітлені в роботах закордонних (R. A.-H. Al-Tantawi, S. A. Al-Zaini, S. A. S. Selim (Selim, Al-Tantawi, \& AlZaini, 2015), K. Ban, M. Kocijancic (Ban, \& Kocijancic, 2011), L. Bryan, S. Daly, K. Hutchinson (Daly, Hutchinson, \& Bryan, 2007) та ін.) і вітчизняних (О.М. Завражна, І.О. Мороз, О.Д. Стадник (Мороз, 2016) та ін.) науковців.

Курс шкільної фрізики побудовано концентрично: перший концентр - 7-9 класи, другий концентр - 10-11 класи. Ураховуючи специфіку навчального матеріалу, міжпредметні зв'язки й навчальні можливості учнів, основою другого концентру $є$ базовий курс фрізики, зміст якого у старшій школі дещо розширює, поглиблює і доповнюється новими знаннями, тому дозволяє продовжити формування ключових і предметної 
Серія: Педагогічні науки. - Вип.3. - Бердянськ : БДПУ, 2019. - 453 с.

компетентностей. Відповідно до цього ми пропонуємо розширити змістове наповнення курсу фізики старшої школи елементами нанотехнологій з урахуванням розробленого нами змістового наповнення (Ткаченко, 2017, 2018, 2019).

Мета статті - розкрити методичні особливості навчання учнів основ нанотехнологій на уроках фрізики в 10 класі.

Методи та методики дослідження. У ході дослідження були використані методи: аналіз, синтез і узагальнення наукової й методичної літератури з проблеми; порівняння та систематизування теоретичного й практичного досвіду для визначення методичних особливостей навчання учнів основ нанотехнологій на уроках фрізики в 10 класі.

Результати та дискусії. Курс фрізики старшої школи розпочинається вивченням механіки. Так, учні 7 класу дізналися про унікальні механічні властивості наноматеріалів - міцність і гнучкість. Вивчаючи тему "Розвиток космонавтики" доцільно поглибити ці знання, зокрема провести з учнями таку бесіду:

- Які засоби сьогодні використовують для польотів у космос, запуску штучних супутників Землі, орбітальних космічних станцій?

- Які недоліки використання космічних ракет? (Маса палива має бути у десятки разів більша маси оболонки, при згоранні палива відпрацьовані ступені ракет забруднюють навколишнє середовище $i$ поповнюють чисельність космічного сміття, значна вартість тощо) ракет?

- Чи існують на сьогодні альтернативи використанню космічних

- Чи можливо сьогодні створити космічний ліфт? Що для цього потрібно?

- Ідея створення космічного ліфта не нова. Основоположник теоретичної космонавтики Костянтин Едуардович Ціолковський ще у 1895 році пропонував створити вежу, подібну до Ейфелевої, висота якої сягала б 35786 км (висота геостаціонарної орбіти). Що ж таке космічний ліфт за сучасними уявленнями? Головним елементом космічного ліфта $€$ надзвичайно міцний трос. На момент виникнення ідеї найміцнішим матеріалом, з якого можна було виготовити трос, була сталь (межа міцності $550 \mathrm{MПа).} \mathrm{Проте} \mathrm{розрахунки} \mathrm{показали,} \mathrm{що} \mathrm{такий} \mathrm{трос}$ зруйнується під дією власної ваги. Відкриття вуглецевих нанотрубок стало поштовхом до створення міцного і легкого тросу. Проте можливості сучасних технологій обмежені й дозволяють створювати вуглецеві нанотрубки довжиною кілька сантиметрів. Альтернативним варіантом для виготовлення троса $є$ графен, межа міцності на розтяг якого становить 130 ГПа. До того ж ученим з Пекінського університету вдалося створити майже позбавлений дефектів лист графену розмірами 500×50 мм. Інші обов'язкові елементи ліфта - базова наземна станція, противага й орбітальна космічна станція, кабінка ліфта. Територіально вигідним $€$ розташування базової наземної станції в Тихому океані поблизу екватора, оскільки урагани й смерчі ніколи не утворюються на екваторі, а блискавки $є$ рідкістю. В якості противаги рекомендується замість важкого 
об'єкта використовувати сам трос, що буде виходити за межі геостаціонарної орбіти. Це пояснюється тим, що трос рухається зі значною швидкістю і може слугувати майданчиком для запуску космічних апаратів. Ще одним не вирішеним на сьогодні питанням $€$ рух кабінки ліфта. Традиційні ліфти приводяться в рух за допомогою механічних механізмів, проте для космічного ліфта науковці планують створити електромагнітний механізм. Аргументують це тим, що електромагнітна система підйому космічного ліфта буде більш ефективною й економною.

Вивчаючи тему “Механічні коливання", доцільно розглянути 3 учнями принцип дії найменших у світі ваг. Щоб підвести учнів до вивчення цього питання, пропонуємо провести таку бесіду:

- Що означає "виміряти масу тіла"? (Виміряти масу тіла означає порівняти ії з масою еталона, тобто тіла масу якого взята за одиницю)

- Що є еталоном маси? (Еталоном маси є платино-іридієвий циліндр масою 1 ке, що зберігається в Міжнародному бюро мір і ваг, м. Севр, Франція)

- Які способи визначення маси тіла вам відомі? (Зважування, порівняння швидкостей тіл після взаємодіі $\left.\frac{m_{2}}{m_{2}}=\frac{\Delta v_{2}}{\Delta v_{2}}\right)$

- Чи можна визначити масу мікроскопічних тіл методом зважування?

- На сьогодні лабораторні ваги дозволяють вимірювати масу тіл з точністю до 1 мкг. То як же визначити масу частинок, маса яких менше 1 мкг? Виявляється, це можливо зробити за допомогою вуглецевих нанотрубок. Так, науковці Технологічного інституту Джорджії створили найменші у світі ваги. В основі їх роботи лежить залежність між частотою коливань і жорсткістю вуглецевої нанотрубки та масою вимірюваного об'єкта $\left(\omega_{0}=\sqrt{\frac{k}{m}}\right)$. До вуглецевої нанотрубки прикладають зовнішню напругу змінної частоти, і коли частота коливань напруги збігається 3 власною частотою коливань вуглецевої нанотрубки, відбувається резонанс. Це дозволяє визначити власну частоту коливань вуглецевої нанотрубки. Якщо на вільний кінець вуглецевої нанотрубки помістити досліджуваний об'єкт, то частота власних коливань зміниться. За цією зміною можна визначити масу досліджуваного об'єкта. Зокрема, науковцям вдалося виміряти масу вуглецевої наночастинки, що становить $22-10^{-15}$ г (рис. 1). Науковці очікують, що такі нановаги будуть застосовуватися при вимірюванні маси великих біомолекул і вірусів (Wang, Poncharal, \& de Heer, 2000). 


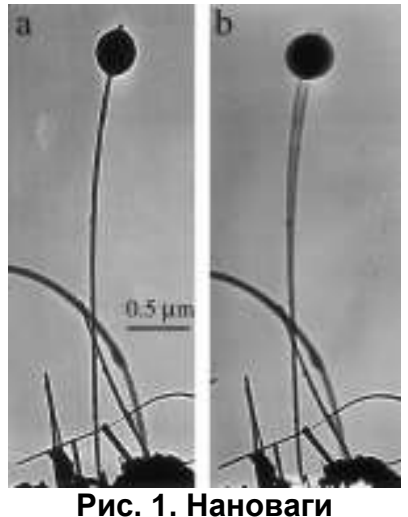

Вивчаючи поняття "капіляр" та "капілярні явища", учні дізнаються, що в повсякденному житті нас оточують об’єкти, пронизані капілярами, наприклад, - папір, ґрунт, дерево, тканини, рослини, будівельні матеріали, живі організми тощо. При цьому варто запропонувати учням з'ясувати

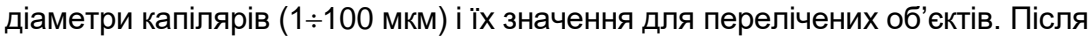
цього вчитель ставить навідне запитання: "Чи існують капіляри меншого діаметра?" У ході бесіди вчитель підводить учнів до висновку, що вуглецеві нанотрубки, як свідчать експериментальні дані, володіють капілярними властивостями, тобто при контакті з речовиною “втягують" ії у себе, причому це можуть бути не лише рідини, а й гази та розплави металів. Задля розвитку творчого мислення, уяви, уміння працювати в команді варто об'єднати учнів у групи для виконання завдання: запропонуйте напрямки застосування капілярних властивостей вуглецевих нанотрубок. Після презентації результатів роботи учні критично оцінюють важливість запропонованої ідеї, її реалістичність, ставлять уточнювальні запитання тощо. Важливо також показати реальне практичне застосування капілярних властивостей вуглецевих нанотрубок. Перш за все їх використовують як контейнери для зберігання i транспортування різних об'єктів. Наприклад, новозеландські вчені з'ясували, що вуглецева нанотрубка поглинає дрібні наночастинки срібла, відсіюючи при цьому більші. Крім того, якщо більша частинка потрапляє на торець вуглецевої нанотрубки, вона "витягує" і "поглинає" менші наночастинки срібла (Edgar, Hendy, Schebarchov, \& Till, 2011). Таким чином, вуглецеві нанотрубки можна використовувати як найменші у світі піпетки.

Проблема пошуку відновлюваних і екологічно безпечних джерел енергії 3 кожним днем стає все більш актуальною. Одним із перспективних джерел енергії $€$ водень: найпростіший і найпоширеніший хімічний елемент у Всесвіті, має велику кількість енергії (для того, щоб подолати 500 км шляху автомобілю, знадобиться близько 3 кг водню), двигуни, що працюють на водні, майже не забруднюють навколишнє середовище. Проте, незважаючи на очевидні переваги, водень як паливо не позбавлений недоліків: майже не існує в природі в чистому вигляді, а 
способи його отримання $є$ вартісними; для зберігання і транспортування використовують масивні балони. Завдяки капілярним властивостям вуглецеві нанотрубки можуть стати основою систем зберігання водню. Для прискорення розвитку виробництва вуглецевих нанотрубок як середовища для зберігання водню в транспортних засобах та керованих паливних елементах науковцям необхідно ще докласти чимало зусиль для відпрацювання механізмів поглинання та вивільнення водню.

Вивчаючи тверді тіла, учні поглиблюють свої знання про їх механічні властивості, зокрема про пружні властивості твердих тіл. У 10 класі вводиться величина - модуль Юнга (модуль пружності) - рівень опору матеріалу поздовжній деформації. Учні порівнюють числові значення модуля Юнга для різних речовин. Крім того, учням варто пояснити, як значення модуля пружності впливає на застосування тих чи інших матеріалів. Так, наприклад, значення модуля Юнга матеріалу варто враховувати при виготовленні різних промислових і будівельних конструкцій, таких, як мости, колони, стовпи, балки тощо. Під час побудови мосту слід заздалегідь адекватно врахувати навантаження, яке він може витримати. Або, будуючи кран, який використовується для підйому вантажів, слід пам'ятати, що подовження канату не перевищує межу пружності мотузки. Щоб подолати проблему згину під силою, насамперед, слід ураховувати еластичну поведінку використовуваного матеріалу.

При вивченні цього питання варто згадати уже відомі учням вуглецеві нанотрубки. Середні значення модуля Юнга для вуглецевих

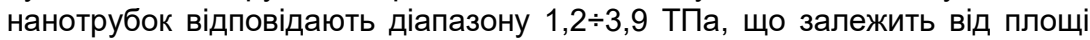
поперечного перерізу взятої вуглецеві нанотрубки і методу розрахунку (Alzubi, \& Cosby, 2015). Таким чином, вуглецеві нанотрубки не лише міцні, а й гнучкі. Досить цікавою $є$ поведінка вуглецевих нанотрубок під дією механічних напруг, що перевищують критичне значення: вони не руйнуються, а перебудовуються.

Доцільно запропонувати учням таке завдання: подумайте i запропонуйте можливі застосування вуглецевих нанотрубок на основі їх механічних властивостей. Відповіді учнів рекомендуємо уточнити й доповнити інформацією про реальні застосування механічних властивостей вуглецевих нанотрубок та їх перспективами. Сьогодні науковці працюють над створенням штучних м'язів на основі вуглецевих нанотрубок для виробництва роботів, протезів, екзоскелетів тощо (Hyeon, Woo, Baughman, \& Jeong, 2019). Штучні м'язи порівняно з біологічними можуть бути в десять разів сильніші, витримують високі температури, вакуум і багато хімічних реагентів.

Ще одним важливим напрямком застосування $є$ модернізація ниток і тканин вуглецевими нанотрубками. Це дозволить шити міцний і легкий одяг для пожежників, правоохоронців, військових, космонавтів, медичних працівників, спортсменів, виготовляти бронежилети. Одним із найбільш розповсюджених текстильних матеріалів $є$ бавовна - легка, не подразнює шкіру, пропускає повітря. Проте вона має погані механічні властивості та швидко займається. Науковцям вдалося нанести сітчасте покриття із 
вуглецевих нанотрубок на поверхню бавовняних волокон, що значно покращило їх функціональні характеристики: покращені механічні властивості, вогнестійкість, захист від ультрафіолету і водовідштовхувальні властивості (Yuyang, Xiaowen, Kaihong, \& John, 2008).

Висновки. Формування в учнів старшої школи уявлень про нанотехнологій $€$ важливим етапом на шляху до підготовки фахівців, здатних розвивати цю нову галузь науки і техніки задля економічного i технологічного зростання нашої країни. Запропоноване змістове наповнення і методичні рекомендації $€$ логічним продовженням курсу фрізики основної школи з урахуванням нанотехнологічної компоненти, що забезпечує наступність і систематичність у навчанні елементів нанотехнологій. Перспективи подальших досліджень вбачаємо у визначенні методичних особливостей формування в учнів уявлень про нанотехнології в курсі фрізики 11 класу.

\section{Література}

1.Нанотехнології в освітній галузі: [колект. монографія] / за заг. ред. І.О. Мороза. - Суми: Вид-во СумДПУ імені А.С. Макаренка, 2016. - 244 с.

2.Навчальна програма для 3ЗСО “Фізика. 10-11 класи. Рівень стандарту. Профільний рівень (авторський колектив під керівництвом Локтєва В. М.)”. - К., 2017. - 34 c.

3.Навчальна програма для 33СО “Фізика і астрономія.10-11 класи. Рівень стандарту. Профільний рівень (авторський колектив під керівництвом Ляшенка O.І.)". - К., 2017. - 55 c.

4.Ткаченко Ю.А. Методичні особливості навчання учнів основ нанотехнологій на уроках фрізики у 7 класі / Ю.А. Ткаченко // Фізико-математична освіта: науковий журнал. - Суми, 2017. - Вип. 3 (13). - С. 108-112.

5. Ткаченко Ю.А. Методичні особливості навчання учнів основ нанотехнологій на уроках фрізики у 8 класі/ Ю.А. Ткаченко //Науковий часопис Національного педагогічного університету імені М.П. Драгоманова. Серія 5. Педагогічні науки: реалії та перспективи. - Київ, 2018. - Вип. 62. - С. 212-219.

6.Ткаченко Ю.А. Методичні особливості навчання учнів основ нанотехнологій на уроках фрізики у 9 класі/ Ю.А. Ткаченко //Вісник Глухівського національного педагогічного університету імені Олександра Довженка: зб. наук. праць. - Глухів, 2019. - Вип. 40. - С. 149-158.

7.Alzubi F. Calculating Young's modulus for a carbon nanotube / F. Alzubi, R. Cosby // Advanced Materials: TechConnect Briefs 2015. - Boston, 2015. P. 137-140.

8.Ban K. Introducing topics on nanotechnologies to middle and high school curricula / K. Ban , S. Kocijancic // 2nd World Conference on Technology and Engineering Education (5-8 September 2011, Ljubljana, Slovenia). - Ljubljana, 2011. - P. 78-83

9.Daly S. Incorporating nanoscale science and engineering concepts into middle and high school curricula / S. Daly, K. Hutchinson, L. Bryan // Proceedings of the Annual Conference of the American Society for Engineering Education (June $24^{\text {th }}-27^{\text {th }}$, Honolulu, Hawaii). - Honolulu, 2007.

10. Edgar K. Reverse Capillary Actionin Carbon Nanotubes: Sucking Metal Nanoparticles Out of Nanotubes / K. Edgar, S. C. Hendy, D. Schebarchov, R. D. Till // Small. - Vol. 7, Issue 6. - 2011. - P. 737-740.

11. Hyeon J. S. Electrochemical graphene/carbon nanotube yarn artificial muscles / J. S. Hyeon, J. W. Park, R. H. Baughman, S. J. Kim // Sensors and Actuators, B: Chemical. - 2019. - № 6. - P. 237-242. 
12. Selim S. A. S. Integrating nanotechnology conceptsandits applications into the secondary stage physics curriculum in Egypt / S. A. S. Selim, R. A.-H. Al-Tantawi, S. A. Al-Zaini //European Scientific Journal. - 2015. - Vol. 11. № 12. - P. 193-212.

13. Wang Z.L. Measuring physical and mechanical properties of individual carbon nanotubes by in situ TEM / Z. L. Wang, P. Poncharal, W. A. De Heer // J. Phys. Chem. Solids. - 2000. - № 61(7). - P. 1025-1030.

14. Yuyang L. Functionalization of Cotton with Carbon Nanotubes / L. Yuyang, W. Xiaowen, Q. Kaihong, X. John // Journal of Materials Chemistry. - 2008. - 18. - P. 3454-3460.

\section{References}

1.Moroz I.O. (2016). Nanotekhnolohii v osvitnii haluzi [Nanotechnology in the educational field]: [kolekt. monohrafiia]. Sumy: Issue of the SSPU named after A.S. Makarenko. [in Ukrainian]

2. Navchalna prohrama dlia ZZSO «Fizyka. 10-11 klasy. Riven standartu. Profilnyi riven (avtorskyi kolektyv pid kerivnytstvom Loktieva V. M.)» [Curriculum for GSEl «Physics. Grades 10-11. The standard level. Profile level (author's collective under the leadership of Loktiev V.M.)»] (2017). [in Ukrainian]

3. Navchalna prohrama dlia ZZSO «Fizyka i astronomiia. 10-11 klasy. Riven standartu. Profilnyi riven (avtorskyi kolektyv pid kerivnytstvom Liashenko O.I.)» [Curriculum for GSEl «Physics and astronomy. Grades 10-11. The standard level. Profile level (author's collective under the leadership of Liashenko O.I.)»] (2017). [in Ukrainian]

4.Tkachenko, Y.A. (2017). Metodychni osoblyvosti navchannia uchniv osnov nanotekhnolohii na urokakh fizyky u 7 klasi [Methodical specifics of teaching pupils the basics of nanotechnology in physics lessons in the 7th form]. Physical and Mathematical Education (3(13)), 108-112. [in Ukrainian]

5. Tkachenko, Y.A. (2018). Metodychni osoblyvosti navchannia uchniv osnov nanotekhnolohii na urokakh fizyky u 8 klasi [Methodical specifics of teaching pupils the basics of nanotechnology in physics lessons in the 8th form]. Scientific journal of the National Pedagogical University named after M.P. Dragomanov, 62, 212-219. [in Ukrainian]

6. Tkachenko, Y.A. (2019). Metodychni osoblyvosti navchannia uchniv osnov nanotekhnolohii na urokakh fizyky u 9 klasi [Methodical specifics of teaching pupils the basics of nanotechnology in physics lessons in the 9th form]. Bulletin of Glukhiv National Pedagogical University named after Alexander Dovzhenko, 40, 149-158. [in Ukrainian]

7.Alzubi , F., \& Cosby, R. (2015). Calculating Young's modulus for a carbon nanotube. Advanced Materials: TechConnect Briefs 2015, 137-140. [in English]

8.Ban , K., \& Kocijancic, S. (2011). Introducing topics on nanotechnologies to middle and high school curricula. 2nd World Conference on Technology and Engineering Education, 78-83. [in English]

9.Daly, S., Hutchinson, K., \& Bryan , L. (2007). Incorporating nanoscale science and engineering concepts into middle and high school curricula. Proceedings of the Annual Conference of the American Society for Engineering Education. [in English]

10. Edgar, K., Hendy, S. C., Schebarchov, D., \& Tilley, R. D. (2011). Reverse Capillary Action in Carbon Nanotubes: Sucking Metal Nanoparticles Out of Nanotubes. Small, 7(6), 737-740. [in English]

11. Hyeon, J. S., Park, J. W., Baughman, R. H., \& Kim, S. J. (2019). Electrochemical graphene/carbon nanotube yarn artificial muscles. Sensors and Actuators B: Chemical, 6, 237-242. [in English]

12. Selim, S. A. S., Al-Tantawi, R. A.-H., \& . A. Al-Zaini, S. A. (2015). Integrating nanotechnology conceptsandits applications into the secondary stage physics curriculum in Egypt. European Scientific Journal, 11(20), 193-212. [in English] 
13. Wang, Z., Poncharal, P., \& Heer, W. D. (2000). Measuring physical and mechanical properties of individual carbon nanotubes by in situ TEM. Journal of Physics and Chemistry of Solids, 61(7), 1025-1030. [in English]

14. Yuyang, L., Xiaowen, W., Kaihong, Q., \& John, X. (2008). Functionalization of Cotton with Carbon Nanotubes . Journal of Materials Chemistry, (18), 3454-3460. [in English]

\section{АНОТАЦІЯ}

Сьогодні якісна освіта покоління, що підростає, $є$ запорукою розвитку, економічного і соціального зростання нашої держави. У статті наголошується, що включення окремих питань з основ нанотехнологій у курс шкільної фізики дозволить оновити його зміст та стане основою для підготовки кваліфікованих кадрів.

Mета статmі - розкрити методичні особливості навчання учнів основ нанотехнологій на уроках фізики в десятому класі.

Проведено аналіз навчальних програм та підручників з фрізики для десятого класу, рекомендованих Міністерством освіти i науки України. У статmі пропонується включити окремі питання основ нанотехнологій у розділи "Механіка", "Молекулярна фрізика та термодинаміка" курсу фрізики старшої школи та відповідні методичні рекомендації щодо викладання окремих питань основ нанотехнологій, розроблені авторкою. Зміст статmі - це логічне продовження раніше визначених методичних особливостей навчання учнів основ нанотехнологій у курсі фрізики основної школи, що сприятиме формуванню в учнів комплексного уявлення про них $i$ забезпечить наступність у вивченні основ нанотехнологій. Формування предметної нанотехнологічної компетентності має стати результатом вивчення окремих питань основ нанотехнологій на уроках фрізики. У статті звертається увага на використання нетрадиційних методів навчання учнів (методи проблемного навчання, інтерактивні методи, проектний метод) при вивченні відповідних питань нанотехнологічної тематики.

Включення окремих питань основ нанотехнологій у шкільний курс фрізики сприятиме формуванню уявлень старшокласників про нанонауку й нанотехнології та їх міждисциплінарний характер і стане важливим кроком до підготовки фрахівців, здатних розвивати цю нову сфреру науки і техніки для економічного, технологічного та соціального зростання нашої країни.

Ключові слова: освіта в галузі нанотехнологій, шкільний курс фрізики, методичні особливості навчання основ нанотехнологій. 